\title{
John of Worcester and the science of history
}

Article

Accepted Version

Lawrence-Mathers, A. (2013) John of Worcester and the science of history. Journal of Medieval History, 39 (3). pp. 255274. ISSN 0304-4181 doi: https://doi.org/10.1080/03044181.2013.798742 Available at https://centaur.reading.ac.uk/30180/

It is advisable to refer to the publisher's version if you intend to cite from the work. See Guidance on citing.

To link to this article DOI: http://dx.doi.org/10.1080/03044181.2013.798742

Publisher: Taylor \& Francis

All outputs in CentAUR are protected by Intellectual Property Rights law, including copyright law. Copyright and IPR is retained by the creators or other copyright holders. Terms and conditions for use of this material are defined in the End User Agreement.

\section{www.reading.ac.uk/centaur}

\section{CentAUR}

Central Archive at the University of Reading

Reading's research outputs online 


\title{
John of Worcester and the Science of History
}

\begin{abstract}
Although the 'chronicle of chronicles' compiled at Worcester c1095-c1140 is now firmly attributed to John of Worcester, rather than Florence, major questions remain. A central issue is that the semiautograph manuscript of the chronicle (now Oxford, Corpus Christi College, Ms 157) underwent several alterations to its structure and contents, as codicological evidence demonstrates. These included the incorporation of important illuminations, which have been surprisingly little considered in their overall manuscript context. This article focuses on these illuminations, and will argue that their presence in this version of the chronicle makes it something even more distinctive than the learned, revisionist chronological work of Marianus Scotus upon which it was based. John of Worcester's chosen images are linked not only to his political narrative but also to theological works and to cuttingedge science, newly translated from Arabic. The presence of such miniatures in a twelfth-century chronicle is unique, and they are central to the final form given to the Worcester chronicle by John of Worcester himself in this key manuscript. Their analysis thus brings into focus the impressive assembly of materials which the chronicle offered to readers, to shape their understanding of ongoing events.
\end{abstract}

Keywords

Chronicles, England, Monasticism, Chronology, Computus, Science, Iconography

John of Worcester was a monk of the Benedictine priory at Worcester Cathedral and one of the most important English chroniclers of the twelfth century. It is now some fifteen years since John was established as the main author of the Worcester chronicle, overturning the traditional acceptance of another monk, Florence, as the holder of that role. ${ }^{1}$ John himself paid tribute to Florence in the annal for 1118 , where the latter's 'acute understanding', 'industry' and 'assiduous labour' are said to have made the Worcester 'chronicle of chronicles' superior to all others; a phrasing which does not actually specify Florence's contribution. ${ }^{2}$ However, questions of authorship are not the only ones which hang over this chronicle. ${ }^{3}$ Paul Hayward recently commented that the whole of what is now accepted as John's chronicle (including the opening section, which has not yet been published in its entirety) constitutes 'an immense text whose complexity has so far defied all attempts to fully report its contents and significance'. ${ }^{4}$ He has also made the innovative suggestion that it, and its shorter derivatives, were linked to the practice and teaching of the science of computus. ${ }^{5}$ This is potentially extremely important, as a reflection of the status of the Worcester chronicle as an ambitious handling of a technical chronological issue; and yet Hayward has to downplay the significance of the account of events in England which most historians have seen as the main point of the chronicle. Finally, neither view takes full account of the presence in the main copy of the chronicle (which is at least partly John's autograph) of highly unusual miniatures, which have been the subject of considerable analysis by art historians. ${ }^{6}$ This article will look at evidence from the whole of this important manuscript (now Oxford, Corpus Christi College, Ms 157), paying particular attention to the illuminations, which are unique both in chronicle-writing and in book production more generally during the twelfth century.

On the question of the authorship and nature of the Worcester chronicle, the main source of direct information is Orderic Vitalis, chronicler of St Evroult, who praises John of Worcester in his survey of contemporary historians. ${ }^{7}$ Orderic stresses both 
that the Worcester chronicle was initiated by St Wulfstan (d. 1095) and that John was continuing the work of Marianus Scotus. The latter, as Orderic says, had set himself to update the world-history of Eusebius and Jerome, and had re-calculated a chronology from the creation of the world to the time of his own death, setting out the reigns of kings and rulers from the Bible, classical history and more recent times. Orderic's account makes it clear that he visited Worcester, perhaps specially to see John's work. Orderic's first comment is that John, who was admirable for both piety and learning (moribus et eruditione venerandus), added an account of the reigns of William I, William II and Henry I (up to the time of writing) to the work of Marianus. An explanation of the achievement of Marianus follows, stating that he had compiled a world history structured by the reigns of kings and consuls, extending to the time of his own death. Next comes the observation that John wove in (contexuit) acts covering about one hundred years, inserting much about the Romans, Franks, Germans, and other peoples, that he knew. John's version adds new lists of all the kings and all the bishops 'in England' since the times of Vortigern, 'king of Britain' and of St Augustine. ${ }^{8}$ The wording is not entirely clear, as Chibnall and others have also noted. ${ }^{9}$ However, the impression given is that a new edition of Marianus' work has been created; and this hybrid is recommended to the reader, along with the even more prestigious world chronicle of Sigebert of Gembloux. As Orderic stresses, both the Worcester chronicle and the work of Sigebert were very new and exciting. Indeed, he uses the conclusion to Book III of his own Ecclesiastical History to praise both.

John's work has been studied by modern historians primarily as a 'substantial English history' organised as a set of annals for the period 450 to 1140 bringing together Marianus and Anglo-Saxon sources. ${ }^{10}$ His chronicle is now valued most for its account of the reign of Henry I, and of the early years of the civil war which followed it, with special attention to Worcester. The coverage of world history pre- 450 is very little discussed. The aim of this present article is to bring to bear a slightly different methodology, drawing on the techniques of manuscript studies. This approach is fruitful, since it results in a new evaluation of the scope and nature of John's achievement. Darlington and McGurk, the recent editors of John of Worcester's work, note that the chronicle was 'well known and frequently used in the twelfth and thirteenth centuries', but are somewhat guarded about John's strengths as an historian. ${ }^{11}$ Brett's important analysis of John's contacts with other Anglo-Norman historians has a similar effect. ${ }^{12}$ On the one hand Brett demonstrates that the priory of Worcester, and probably John personally, exchanged texts or information with scholars from Malmesbury, Canterbury, Durham and St Evroult, at least, and that copies of John's chronicle reached Coventry, Abingdon, Bury St Edmunds and Peterborough during the twelfth century. On the other hand the annalistic structure used by John is held to have limited the extent to which he could offer 'a general view of the causes or purpose of human experience'. John is judged to be inferior to William of Malmesbury as a researcher, and to Eadmer of Canterbury as an observer of contemporary events. In place of broad perspective, the best John can offer is 'a mass of precious details of chronology'. ${ }^{13}$

Brett's analysis established John of Worcester as an important member of a school of 'monastic historians' whose work was affected by the challenges and threats faced by their own monasteries. ${ }^{14}$ These threats were very real for English monastic houses both in the period which followed the Conquest and again during the reign of 
Stephen; and the works of chroniclers such as Symeon of Durham and Eadmer of Canterbury do indeed set out and defend the rights and traditional claims of their respective houses. However, Worcester under St Wulfstan responded to the postConquest problems first and foremost by intensive work on its impressive archival resources, as demonstrated by the cartulary known as Hemming's cartulary in particular. This work, together with Bishop Wulfstan's legal skills, underpinned the successful repossession of 'lost' estates, and needs to be taken into account when analysing Worcester's chronicle as a response to local events. ${ }^{15}$ Moreover the range of surviving, late-eleventh-century updatings of the Worcester archive shows that Wulfstan was able and willing to put a whole team of archivists and scribes to work.

Hemming not only gave his name in his late-eleventh-century cartulary of Worcester cathedral priory but also recorded in an unusually personal, narrative introduction that he was working under the authority of Saint Wulfstan. His work now survives in ten quires within British Library Ms Cotton Tiberius A xiii. Analysis of these shows that Hemming and the scribes who worked with him were well informed and working to a clear purpose. They had access not only to the Worcester archive but also to the entries relating to the bishop and priory of Worcester in what Hemming calls cartam regis quae est in thesauro regali - in other words, to Domesday Book. Moreover, Hemming states that Wulfstan himself collected the early charters and the leases of Bishop Oswald, and 'arranged them in two volumes'. ${ }^{16}$ He also notes yet another archival collection, in the form of a copy of key documents added into the Bible of the Church of Worcester, fragments of which survive in British Library, Mss Cotton Nero E i and Add. 46204. The Worcester scribe who copied these documents for addition into the Bible perhaps worked directly under the supervision of the bishop. A multilayered set of records to maintain both Worcester's links with its great founders and patrons and the documentary basis for its landed resources was thus produced. Since it was also Bishop Wulfstan who chose to have a world chronicle compiled at Worcester, based on the work of Marianus Scotus, it follows that John of Worcester's chronicle was intended as something different from a local, institutional history. At Durham, by contrast, Symeon focused on just such a 'local' history, calling his work a Libellus and making use of sources such as a 'charter-roll of the church, showing the munificence of kings and persons in religion'. ${ }^{17}$ The Worcester project was, as Orderic Vitalis shows, different in structure and range.

This raises the question of just what was the nature of John's 'chronicle of chronicles', especially since work on the chronicle project probably continued for at least forty-five years. Moreover, John and the Worcester team appear to have produced at least two additional versions. The first of these, known as the Chronicula, is in what is probably John's own hand to 1123, but was later extended to 1141 , with Gloucester interpolations. ${ }^{18}$ The other, of which only one leaf survives, seems to have been a fair copy, made at Worcester and used as an exemplar for the Coventry and Abingdon versions of the chronicle. ${ }^{19}$ The creation of the Chronicula emphasises the fact that the editing and updating of a world chronicle was an ambitious undertaking which demanded technical expertise in a range of fields, not all of which were of interest to all readers. Indeed, the increasing attention to the English peoples and kingdoms from $450 \mathrm{CE}$ onwards in the Worcester chronicle does suggest a move away from Marianus' original concept, as Orderic also implies. A final issue is that the impressive miniatures, in the form of tinted drawings, in the semiautograph manuscript of John of Worcester's work (Oxford, Corpus Christi College, 
157) emphasise an apparently wide range of themes: the dream-visions of Henry I; astronomical phenomena; the cross of Christ; and prophets of the Crucifixion. Their presence has led to suggestions that John of Worcester's work should be seen as an early form of illustrated chronicle, something which their impressive quality would appear to support. ${ }^{20}$ However, as yet no full explanation of their content and placing has been produced.

An associated puzzle is that John of Worcester, despite having been commissioned to produce his chronicle by Bishop Wulfstan himself, does not appear to have composed other sorts of historical writing for Worcester. It is perhaps not surprising that the compilation of the cartularies, which required detailed knowledge of the archives relating to the estates and legal position of the priory of Worcester, was entrusted to different members of the community. What is more striking is that John was apparently not asked to undertake any hagiographical writing, even though other chroniclers certainly did turn their hands to such work, and several important Lives were commissioned during his period of activity. When an updated Life of St Oswald, taking into account the miracles associated with the recent rebuilding of the cathedral and translation of the relics, was needed c1115 it was to Eadmer, historian and hagiographer of Canterbury, that the Worcester community turned. And when, about a decade later, a Latin version of the Life of St Wulfstan himself was required, translating and replacing the Old English version by the Worcester monk Coleman (who had been chaplain and chancellor to Wulfstan and died in 1113), it was William, historian and hagiographer of Malmesbury, whom Prior Warin of Worcester asked to undertake this extremely important work. ${ }^{21}$ Given the careers of Eadmer and William themselves, it is clear that history and hagiography were a common combination. Thus in this way John of Worcester's historical work was different from that of other Anglo-Norman monastic historians. Evidence to be considered here strongly suggests that the range of expertise required by the world history took John in a different direction.

Central to this argument is the nature of Marianus Scotus' world chronicle. It was one of a group of eleventh and early twelfth-century works which offered varying solutions to the problematic disjuncture between: the fundamental chronological work of Dionysius Exiguus; the associated science of computus; and the indications offered by scripture as to the date of Christ's Passion. ${ }^{22}$ Marianus also followed the structural model of the Chronicle of Eusebius, as updated by Jerome, which began with a Chronographia, setting out sources and data, followed by Chronological Tables for the kingdoms of the known world. ${ }^{23}$ This had established a new, Christian, system of time and dating, calculating from the birth of Abraham in ten-year intervals, and offering a sort of rapid reference guide to the eras of world history, shown in parallel to one another. Marianus Scotus had introduced a further, still more technical, element to his tables, besides covering another seven centuries of world history. Having examined the sixth-century calculations of Dionysius Exiguus, the base upon which the western Christian calendar, chronology and computus were built, Marianus, along with other expert computists, had found Dionysius wanting. Like Abbo of Fleury before him, Marianus adhered to the traditional date of 25 March for the Crucifixion, to which St Augustine had given his support - but noted that 25 March in the year identified by Dionysius as that of the first Easter did not coincide with a Friday or with day 14 or 15 of a lunar month, as the Gospels required. For the computistical and scriptural data to align, Christ's Passion had to be placed in a 
different year. Marianus, again like Abbo, chose AD 12, and accordingly re-dated the Incarnation to $22 \mathrm{BC}$. As the author of a world history, Marianus further re-calculated both the year in which the world was created and the Christian era in relation to it. The technical arguments for this were set out in his work; and illustrated by his updated chronological tables. ${ }^{24}$ Such work affected the dating of all events from the Incarnation of Christ onwards and hence risked undermining the status of the year of incarnation as a dating system. Moreover, it depended upon both complex scriptural analysis and challenging mathematical calculations. Finally, readers of both Bede and Abbo of Fleury (who doubtless existed at Worcester c1100) would be aware that Marianus' solutions were not the only possible ones. Appraisal and updating of Marianus' work was thus very much a matter for specialists.

At the heart of the problem were Dionysius' crucial Easter Tables, and the argumenta appended, giving explanations and demonstrations. ${ }^{25}$ No less an authority than Eusebius had first put on record the key decisions affecting the celebration of Easter. ${ }^{26}$ The Council of Nicaea had decreed that all Christians should have a standard method of calculating the date of Easter, but had not provided any technical instructions or guides. Further complications were caused by the fact that Alexandrian and Roman scholars took different views on the necessary reconciliation of solar and lunar calendars. Thus the earliest attempts at Easter Tables incorporated errors which quickly became serious. ${ }^{27}$ Dionysius Exiguus' Latin version of the Alexandrian calculations, adjusted to the Roman calendar, was badly needed. He provided the information required in order for Easter Sunday to be correctly calculated. He then linked this to a radical proposal, namely to adopt a universal, Christian, system for numbering years from the Incarnation of Christ, and went on to apply this from 532 onwards. ${ }^{28}$ Both this proposal and Dionysius' tables gained acceptance in western Europe over the following centuries; and this very fact made the technical problems in his work a serious matter.

Dionysius had provided fundamental versions of: the epacts, or the days added to the age of the moon each year; the concurrents, or adjustment in order to calculate days of the week; and the number of each year within its nineteen year luni-solar cycle. These were the keys to unifying the lunar and solar calendars. Finally he gave the 'Roman' date of the relevant luna 14 each year, the consequent date of Easter Sunday, and the 'age of the moon' (that is, the day of the lunar month) on that Sunday. ${ }^{29}$ This was extremely useful; but skilled computists and mathematicians, at least from the Venerable Bede onwards, could not help noticing the problems with Dionysius' apparent datings of the birth and resurrection of Christ. ${ }^{30}$ Dionysius' information gave a date of 27 March for the first Easter Sunday, with luna 14 on 24/25 March. However, these dates do not appear in any year of Dionysius' cycle which corresponds with Gospel evidence for the age of Christ at his Passion. ${ }^{31}$ As already noted, Marianus was not the only scholar to address this issue; but he was the first to recalculate history, back to the creation of the world, to make available scriptural and computistical data fit. Analysis of his work was clearly a highly technical matter, bringing together computus, chronography, chronology, history and theology, and was something which could be undertaken by very few scholars. One of these few, however, was Bishop Robert of Hereford, a scholar from Lorraine who was one of the foremost experts of the time in the required scientific fields, and who had not only brought Marianus' work to England but also recommended it by writing an introductory treatise. $^{32}$ 
Robert was a close friend of Wulfstan of Worcester, and both this treatise and Marianus' own work survive in copies known at Worcester in this period. They are now in Oxford, Bodleian Library Ms Auct F I 9 and London, British Library, Ms Cotton Nero C v respectively. ${ }^{33}$ It was Wulfstan himself, according to Orderic Vitalis, who ordered the Worcester chronicle to be composed upon the basis of Marianus' work. Wulfstan's exact instructions are unknown; but the evidence of Corpus 157 makes it clear that the Worcester chronicle was not a simple copy of Marianus' work, but rather a new version, which followed his recalculated world history with care but made substantial alterations and additions to the preliminary lists and tables. These will be discussed further below, but the necessary conclusion is that Wulfstan chose scholars to work on the chronicle who possessed the requisite skills. In addition to this there is the testimony of Orderic Vitalis, discussed above. Whilst some of Orderic's details are unclear, he nevertheless appears convinced that John was making a significant contribution to the learned tradition of world history. This testimony is worth taking seriously, since Orderic was himself a skilled chronographer, who placed related tables and calculations before his own Ecclesiastical History. Orderic had also taken pains to see a copy of the new work of Sigebert of Gembloux, another expert on these matters, and places John of Worcester's work on a par with Sigebert's. ${ }^{34}$

The technical and apparently repetitive nature of computistical and genealogical tables has made them of little interest to editors until rather recent times, and the preliminary sections of John of Worcester's work are yet to be published in full. However the whole of the key manuscript, now Oxford Corpus Christi College 157, is available online, thanks to the Early Manuscripts at Oxford University website. It is thus possible to gain a sense of the extent to which John and the Worcester chronicle team added to Marianus' work. Comment has also been provided by Hayward, who argues that the Worcester chronicle, or at least shorter derivatives like the Winchcombe and Coventry chronicles, were linked to the practice and teaching of computus. ${ }^{35}$ As Hayward establishes, in Books One and Two of the Worcester chronicle Marianus' calculations on the age of the world and the dating of key events in Christ's life are faithfully followed. However, the extent of the work undertaken at Worcester is evident in the section containing the lists of rulers and church leaders, where what has been identified as John of Worcester's own hand frequently appears. Strikingly, this material corresponds with one of the portions of the work in which Orderic Vitalis showed interest. Since he visited Worcester before 1124 and Corpus 157 was apparently begun as a fair copy a few years later, what Orderic saw was presumably work in progress. If correct, this would explain the ambiguities in Orderic's description of the Worcester chronicle at this stage.

Analysis has shown that the earliest stage of the 'Worcester' preliminary sections was based directly on the materials which Marianus Scotus had prefixed to his own chronicle. $^{36}$ These consisted of: consular tables; a list of popes; a 'great cycle' of 28 Easter tables, each covering one nineteen-year cycle; and some computistical notes. When they were copied into Corpus 157 the consular tables and their accompanying annals had already been extended to 1100, and lists of bishops of Jerusalem and 'Hebrew pontiffs' added. This in itself would have required considerable research. Growing expertise subsequently enabled the Worcester version to expand Marianus' 
lists of Hebrew judges, priests and kings (see especially Corpus 157, pp. 37 and 38). Original, painstaking work appears from p39 to p46 in the form of episcopal lists for the dioceses in the southern English kingdoms, then the midland ones, and finally the northern ones. All are carefully set out within complex, coloured frames. The lists for the kingdom of the Picts (p46) appear to be an addition, since they are differently set out and accompanied by lengthier text. As McGurk points out, the latest entries in the original version of the episcopal lists were Ralph, archbishop of Canterbury from 1114, and Theulf of Worcester, who was appointed in 1113 and consecrated in $1115 .^{37}$ That these lists were not simply taken from a version of the Anglo-Saxon Chronicle or from the work of William of Malmesbury has been established by the analysis of Stanislav Mereminskiy. ${ }^{38}$

Further newly-edited work followed, in the form of genealogical tables from Adam to the founders of six chief Anglo-Saxon kingdoms (p47) and genealogical trees for the kings of each kingdom (pp48-53). John then cross-referred these with his lists of English dioceses and their bishops, succeeding in providing dates for several figures, including Ecgwine, bishop of Worcester. ${ }^{39}$ The genealogical tables are brought up to date on p54, with lists of members of the house of Godwin and of the Anglo-Norman rulers of England. The Worcester chronicle then reverts to following Marianus: on p55 are the short computistical texts; while pp56 to 69 contain Marianus' 'great cycle' of Easter tables with three sets of brief accompanying annals (updated to 1100). All this material, with the various complex mises-en-page required, was copied by one scribe. Slightly later came some rather radical revisions, requiring the erasure of the original lists of popes and of patriarchs of Antioch, and the insertion of a bifolium into quire three. In the space created a revised text on the popes was entered. ${ }^{40}$ This goes up to Honorius II (1124-30) and is at least partly in John of Worcester's hand, which appears also in further new additions to the manuscript. The first of these is a history of the diocese of Worcester, related to the work on the Worcester archives, which occupies folios 1 and 2 and p3 of Corpus 157 and is mainly the work of another scribe. The next, on part of p4, is a list of kings of the Franks to Louis VI (d1137) and of dukes of Normandy, which appears to be in a formal version of John's hand.

Thus far, even though work had apparently been ongoing from before St Wulfstan's death in 1095 to c1130, the project fits within what might be expected of an updated, Worcester revision of Marianus' work. However other aspects of Corpus 157, including further revisions to the preliminary texts apparently made at the same relatively early stage, point to more complex developments. The first of these begins on a single leaf, now pp71-2, which was inserted after the Easter Tables. John's hand appears again on the section of which this forms a part, whose pages are now confusingly numbered 70-76 and 77a-c. Pages 70 and 71 draw on Marianus' arguments to compile tables of years from the beginning of the world, offering 'rational proof' and 'gospel truth' as to key dates as well as citing Eusebius and Bede. Also on p71 is a table of days of the week for 1 January across a whole 'great cycle'. Rather more surprising is the insertion of a complete text (without diagrams) of Bede's De locis sanctis, beginning on $\mathrm{p} 72$ (the 'verso' of p71). Bede's work ends on p77a, the recto of another, added, single leaf, on whose verso is perhaps the most surprising of all the new texts. This, on what is now $\mathrm{p} 77 \mathrm{~b}$, has no heading or rubric, and lacks its opening initial A. It deals with the allegorical and spiritual significance of the dimensions of various portions of the Cross of Christ, and it overlaps onto the frame of the iconographically unique Crucifixion miniature which occupies the lower 
section of the page. There is a clear relationship between Bede's work on the holy sites and a text on Christ's cross; but there is equally no doubt that their insertion into Corpus 157 adds still further to the complex concerns of the chronicle. The reader is implicitly invited to meditate upon the location of the Passion as well as its date; while the text accompanying the Crucifixion miniature considers both the dimensions of the Cross and its power as a link between this world and the next. The measurement of time and space is given a clear spiritual overtone, and this is reinforced by the visual imagery.

The miniature on $\mathrm{p} 77 \mathrm{~b}$ has attracted discussion, both for its impressive execution and for the rarity of its iconography. At first glance it looks like a standard image of the Crucifixion, with a female figure standing under one arm of the Cross and a male figure under the other. However, it rapidly becomes clear that these are not the standard figures of the Virgin and St John. The female figure originally had no nimbus (though a sketchy one has been added in a later hand) and holds a scroll and two crossed sticks, and thus cannot be the Virgin. The male figure also has no nimbus, is holding a scroll, and is standing on a large fish - not a standard attribute for St John. Michael Kauffmann accepted that the female figure is the Widow of Sarepta, who was encountered by Elijah gathering sticks, and whose son he raised from death (I Kings 17), and this has been generally followed. ${ }^{41}$ However, this identification does not entirely explain why she holds a scroll, an attribute normally reserved for prophets. It is also the case that, whilst the Widow of Sarepta, with her two sticks, was accepted as a type for Christ carrying the Cross in English art by the end of the twelfth century, that does not entirely fit with her early appearance here, accompanying the Crucifixion itself.

Swarzenski's suggestion that the figure might be a combination of the Virgin and the Widow of Sarepta is attractive; but it is also possible to propose another hypothesis. ${ }^{42}$ Central to this is the fact that work on the chronological section of Corpus $157 \mathrm{had}$ entailed much careful and detailed reading of Bede, Eusebius and Jerome. It is also the case that the creation of typological cycles was still something new in the early twelfth century, leaving scope for originality. ${ }^{43}$ A careful reading of Bede would challenge the inclusion of the Widow of Sarepta in a Crucifixion scene, since Bede, discussing the pictures brought back from Rome by Benedict Biscop, makes a distinction between Old Testament images linked to the carrying of the Cross and those which paralleled the Crucifixion itself. ${ }^{44}$ It is Eusebius whose work suggests an alternative interpretation. His Chronicle stressed that Christianity was the successor to both Judaism and Roman paganism; and his Life of Constantine made the emperor himself, in an oration supposedly delivered to the Assembly of the Saints, a supporter of this view. ${ }^{45}$ Moreover, Constantine's oration placed great emphasis on the prophetic role of the Sibyls, and quoted the whole of the Sibylline prophecy later discussed by Augustine in his City of God. ${ }^{46}$ The version given by Eusebius forms an acrostic which renders the words 'Jesus Christ, Son of God, Saviour, Cross'. To emphasise the status of the Sibyl as prophet, Eusebius/Constantine goes on to call her a virgin, and to show that she prophesied the coming of a Virgin, together with a king. Eusebius even has the emperor discuss the issues of dating and chronology, in order to prove that the Sibyl lived and prophesied before the birth of Christ. Eusebius does not mention the fact that if the initials of the 'hidden' words, in Greek, are put together, then the Greek word for 'fish' is produced. However, this had already been noted by Tertullian and was taken up by Augustine, who incorporated it into his own 
discussion of the Sibyl's prophecy. ${ }^{47}$ The result of all this is to bring together: a virgin prophetess; Christ; the Cross; and a fish. And the combination of a fish and a male prophet, accounting for the second figure in the Worcester illumination, can be found in Jonah, whose swallowing by the whale was stated by Christ himself to have prefigured the three days and three nights during which the Son of man would be in the heart of the earth (Matthew 12, 40).

This reading of the Worcester miniature offers an explanation of both its unique iconography and its placing as a link between the expanded preliminary section and Marianus' world history proper, which follows on p77c with a Prologue on the dating of the first Easter. That the miniature was specially designed for this placing in this chronicle is strongly suggested by Judith Collard's research into twelfth-century chronicle illumination. Like Michael Kauffmann somewhat earlier, Collard concluded that chronicle illustration was a rarity before the thirteenth century. ${ }^{48}$ Only the chronicle of St Martin des Champs (now B.L. Ms Add. 11662) datable to c1070, offers an earlier example; and this is very different. Its illuminations, on ff. $4 \mathrm{r}$ and $5 \mathrm{v}$, show kings Henry I and Philip I of France as donors to the monastery, and they are very much more representative of monastic illustration of secular texts than Corpus 157. Where illustration occurred at all in chronicles (or cartularies and records such as the Liber vitae of New Minster, Winchester) it was devoted to powerful patrons and saintly founders. ${ }^{49}$ The insertion of the Crucifixion miniature into Corpus 157 was thus a significant decision in itself. That it puzzled contemporaries is suggested by the evidence of Bodleian Library, Oxford, Ms Bodl. 297. This is the Bury St Edmunds copy of John of Worcester's chronicle, and is a copy so faithful that it has been argued that it could only have been made from Corpus 157 itself. $^{50}$ However, the Bury copy has only an unfinished sketch of the Crucifixion miniature. The artist/s removed both attributes from the female figure, but did not give her a nimbus. Of the male figure they seem to have made nothing at all. The Bury copyists appear to have been prepared to follow Corpus 157 in having a Crucifixion miniature at the same point in the text, but to have been uncertain as to its accompanying figures.

It thus seems that the Worcester Crucifixion was inspired directly by work on the computistical, genealogical and world-historical sections of the chronicle. That interest in prophecies would have been encouraged by study of Eusebius is suggested by his collection of messianic prophecies into the Eclogae Propheticae. Moreover, whilst twelfth-century depictions of the Sibyl are rare, all known examples emphasised her role as a prophet. The precedent was set by the late-eleventh-century frescoes in Sant'Angelo in Formis, which included the Sibyl amongst the prophets of Christ. In 1169 the Sibyl was depicted in mosaic, together with biblical prophets and with Balaam's ass, on the west wall of the Church of the Nativity in Bethlehem. ${ }^{51}$ A related image survives in a luxurious Psalter believed to have been made for Ingeborg of Denmark (queen of France) at the end of the twelfth century. This is now Chantilly, Musée Condé, Ms 9/1695, and f 14v has a full-page miniature of a Jesse Tree, flanked by prophets, with the Sibyl at top right. Unlike her scriptural counterparts, and like the figure in Corpus 157, the Sibyl here has no nimbus; and her attribute is a prophetic scroll. Finally it should also be noted that Worcester had another possible reason for interest in the Sibyl and her prophecies in the early twelfth century and that was the probable presence of the scholar, Honorius Augustodunensis. He had studied for some time at Canterbury with Anselm before moving to 
Worcester, and certainly knew of the recently discovered prophecies of the Sibylla Tiburtina, which he cited in his Gemma animae. ${ }^{52}$

It was possibly whilst he was at Worcester that Honorius wrote his Sigillum Beatae Mariae, a copy of which survives in a contemporary Worcester manuscript, now B.L. Ms Royal B IV. That this work was of interest to John of Worcester is demonstrated by its presence, together with other texts of clear relevance to the Worcester chronicle, in a collection of excerpts and short treatises which is now Cambridge, University Library, Ms Kk iv 6. This volume contains many of St Jerome's discussions of aspects of the textual contents of the Old Testament and their significance; and adds a paragraph on the Hebrew alphabet (on folio 31). Jerome's works on the houses of the sons of Israel, on Hebrew names and on illustrious men are all here; and the industry of the Worcester team is shown by the presence of works by the encyclopaedist, Isidore of Seville, and by Gennadius, on related subjects. Calculations on scriptural geography and on the allegorical significance of certain people, places and objects are suggested by the inclusion of Hugh of St Victor's work on the Ark together with extracts on Psalm One, the Temple, Solomon and other subjects. There is also (on folios 108 to 113) a set of extracts focused on the mystical significance of figures from the Old Testament, related to typological study. The final section of the manuscript, folios 224 to 280, contains a copy of the Lives of the Popes, taken down to Calixtus II, and relevant to the revision of Corpus 157. Much of this manuscript has been identified as being in John of Worcester's own hand, although the Lives of the Popes was copied by another scribe and annotated by John. ${ }^{53}$

The extent of this study may also suggest that work on the chronicle was linked to Worcester's precocity in the development of typology in the first half of the twelfth century. Once again Eusebius provides important pointers, since he had also given an endorsement to typology, and even linked it to computus. He pointed out, in his treatise 'On the Celebration of Easter', that Easter was both the 'birthday of the world' and the festival of Christ 'the great luminary'. He writes here of the Passover as amongst the 'shadows of things to come' before celebrating Easter's combination of the Spring equinox and a full moon (Bk I, Chap 2). It falls, as he says, at the 'head of the year, when the sun begins to traverse the first house of the zodiac', and when the anniversary of creation itself takes place (ibid, chap 3). Worcester's groundbreaking typological work is demonstrated by a twelfth-century manuscript, now Worcester F 81, containing verses which appear to record a cycle of typological paintings in the Worcester chapter house. ${ }^{54}$ The paintings are lost, but Heslop has suggested that they could have been executed c1120, making them contemporary with the chronicle project. ${ }^{55}$ No one who entered the chapter house, as reconstructed, could fail to be impressed by the structured display of sacred history presented. ${ }^{56}$ The level of ambition of scholars at Worcester was clearly very high, and the 'chronicle of chronicles' was a fittingly impressive exercise in revisionist history. What remains to be seen is whether the revisions and illustrations added to the final sections of Corpus 157 raised the account of contemporary events to a similar level.

As Martin Brett first demonstrated, John of Worcester's account of the whole period from 1102 to 1140 was built up in complex stages, linked to considerable broadening of the contacts between Worcester and the chroniclers of other houses in both England and Normandy. ${ }^{57}$ Perhaps most influential at Worcester was Eadmer of Canterbury's Historia novorum (completed 1122), but the impact of texts received 
from Durham, Coventry, Abingdon, Gloucester, Bury and Malmesbury has been analysed. ${ }^{58}$ The chronicles of Rouen and of Hugh of Fleury were also apparently acquired, perhaps via St Evroult. ${ }^{59}$ Examination of the manuscript also shows that Corpus 157's original entries for the years 1128-31 were erased, and that a new final section of the chronicle was entered into the manuscript. This now ends abruptly in the annal for 1140, due to the loss of at least one folio from the Corpus manuscript (though a later copy takes it a little further). ${ }^{60}$ The effect of this revision is to rewrite part of this account of Henry I's reign, before continuing on to deal with his final years and then with the outbreak of civil war in England. This section of the chronicle departs from the preceding portions in several ways; but the unprecedented insertion of four narrative miniatures into the annal for 1130 (recte 1131) is one of the most striking. These are the well-known images of the three visions of Henry I, followed by his miraculous escape from death at sea. The first three have been frequently reproduced as illustrations of the three estates of medieval theory; but this has tended to obscure the fact that their appearance in the autograph manuscript of John of Worcester's chronicle is in fact extraordinary. Equally worthy of attention is their context, for these miniatures are preceded by an account of sunspots, accompanied by another unique illustration, and by a very precise and scientific account of a 'vision' of lights in the night sky over Hereford. They are followed by a long account of how the saintly Odilia of Hohenburg was helped by a dream to bring about the return of her father from the dead in order that he might complete his penance. After this comes the story of how the Worcester monks aided the penance of the dying Uhtred, their cantor, by striking him violently for days at a time, and of how he was granted a very good death.

Even from this short summary it is clear that the miniatures, and the story of Henry I's dream-visions which they accompany, work within the manuscript on more than one level. Moreover the reader is prepared for this in several ways. As already demonstrated, the transition from the opening section to Marianus' complex analysis of the calculation of world history (and of the life of Christ in particular) is marked by the specially designed Crucifixion miniature. On reaching p.189 the reader finds a coloured diagram of Christ's cross placed in the text of the right-hand column, at the point where Marianus is assembling authoritative texts as to the significance of the cross and its measurements, and thus echoing the preceding miniature and its texts. Similarly the innovative move of placing the cross diagram within the column of text itself is echoed by the image of sunspots entered into the text of the 'new' annal for 1128. The text on p.380 describing the sunspots, detailed as it is, nevertheless occupies only a few lines in a printed edition and thus appears as a very minor part of the annal. However, it follows the account of the council at Westminster where the leaders of the realm had sworn to accept Matilda as her father's heir, within which the king's sharp reprimand to the abbot of Bury St Edmund's is set out in red. Also emphasised in red is the chronicler's exclamation of grief that this solemn oath has been turned into perjury. Immediately below, central in the column of text, is the sunspot diagram, with the cardinal points of the disc of the sun picked out in gold and thus emphasising the positions of the black spots both in relation to the sun and to one another.

The next opening, made up of pp. 382 and 383, is still more striking. In the top third of p. 382 is the description of the apparition of midnight lights over Hereford. This would be extremely hard to illustrate, given the complexity and scale of the 
observations recorded, and has no accompanying diagram. However it forms a sort of preface to the complex, highly illustrated, record of Henry I's visionary and miraculous experiences. In the first three of these the text is almost reduced to the status of a commentary on the images, which present the king, his dreams, and Grimbald, his doctor, who is both observer and interpreter. Each of these first three miniatures is divided into two parts: at the left, accompanied by a narrow column of text, is Grimbald; and taking up most of the main text column is Henry I in bed, asleep, with the subjects of his visions looming over him. In these images Grimbald is as large as the king himself, and his qualifications are emphasised. He is first shown holding the diagnostic tool of a flask, then an elaborate container (presumably for medicaments), and finally a pair of writing-tablets. The images of the king focus upon his actual visions, and do not show his reactions, which were to leap out of bed and to seize his weapons. However, these dramatic actions are recorded in the caption surrounding the first two pictures of Grimbald, the learned witness to all this. The text inserted around the separate parts of these miniatures combines Grimbald's testimony with exclamations by the chronicler, the last being extended below the level of the miniature itself in order to accommodate a comparison between this event and the dream of King Nebuchadnezzar, interpreted by the prophet Daniel. We are told that, just as Daniel recommended royal penance in the form of alms-giving, so also did Grimbald.

The fourth miniature, the largest of all, directly illustrates the chronicler's own account of how the king, not yet having acted upon Grimbald's interpretation of his visions, came close to death in a storm at sea. This inspired him to make a solemn vow to undertake two forms of penance: remitting Danegeld for seven years; and transforming his journey into a pilgrimage to the shrine of St Edmund at Bury. This would take him to the monastery of the abbot whom he had publicly humiliated at the council. Informed readers will also have been aware of a comparison which John does not spell out. An important post-mortem miracle of St Edmund was the saint's execution of the Scandinavian King, Swein, as retribution for the king's unjust taxation. $^{61}$ The Corpus 157 miniature shows Henry in the act of making his own vow, as the elements threaten his ship. Its outcome, and the fact that he kept it faithfully until his death, are recorded in the column of text to the far right of the miniature. This concludes with the observation that his successor, Stephen, who made a related vow, has committed a perjury odious to God. ${ }^{62}$ As the quatrain set out below the miniature emphasises, the result is that justice is corrupted and denied. Lastly come the concluding words of the annal itself: 'Hoc nefandum scandalum movet veridicum dictum, sicut compositum est'. Stephen's oath-breaking has overturned both his vow and that of his predecessor, as set out [compositum] in these pages. Here is a possible explanation for the unprecedented step of inserting these miniatures into the chronicle; they are part of a battery of evidence offered to inform the reader's judgement on the events recorded.

This hypothesis helps to explain another highly unusual feature of this section of the Worcester chronicle, namely that both miniatures and text are presented together with a complex scientific apparatus. The scholarship involved was partially very new indeed, and related to what seems to have been a new phase of study by those involved with the Worcester chronicle. This is a complex matter since the measurement of time and the associated calculation of planetary movements were traditionally the responsibility of the sacrist or cantor within a Benedictine house. 
The duties of the cantor could include both the calculation of Easter and the timing of services, a fact which helps to explain the degree of respect expressed for Uhtred, cantor of Worcester, in the annal for $1132 .{ }^{63}$ Detailed measurement of time was required in order to ensure that nocturns were finished at the correct interval before matins, which itself must start at daybreak (Benedictine Rule 8.4). Similarly, vespers should take place at a time which allows for the evening meal to be eaten without needing candles and for compline to be finished before full darkness (Rule 41.8). Given the absence of accurate clocks, the need for careful observations of stars, and for tables of their times of rising, adjusted for location and seasonal variations, is clear. ${ }^{64}$ Their association with the computus is demonstrated by the appearance of star catalogues in contemporary computistical collections such as those from Peterborough, Winchcombe and Malmesbury. ${ }^{65}$ Lanfranc's influential Monastic Constitutions had made the sacristan responsible for the timing of matins and thus for making sure that the necessary observations were made. ${ }^{66}$ However, in practice the offices of cantor and sacristan could overlap. ${ }^{67}$ Moreover, William of Malmesbury's comment that St Wulfstan had more time at night for personal prayer when sacristan than he had had as cantor further suggests that the cantor was kept busy during the night. $^{68}$

Whether or not John had been Uhtred's pupil, the concluding section of Corpus 157 shows a new level of technical expertise and provides an unprecedented range of learned and scientific material in association with the events and phenomena recorded. ${ }^{69}$ An example is the account in the new annal for 1130 of how two priests and two clerks at Hereford, leaving the church in the middle of the night, immediately after Lauds, saw an extraordinary vision, in the form of a bright light in the sky. ${ }^{70}$ Not only was this precisely measured at one perch in length, but its location in relation to the horizon was exactly given - it occupied the position of the setting sun at the end of the tenth hour on the day of the summer solstice. This is the sort of language used in treatises on astronomical observation. Further details relating to a dark object from which the light came, and to a white cloud which intermittently covered it, were also recorded. The main witness also provided the information that he had seen two lines of light, stretching from the point where the sun rises above the horizon on the day of the equinox to that where it sets on the same day. The recording of such phenomena is by no means unusual in itself, but earlier sections of John's chronicle handle them in a much simpler way. What is new here is the combination of precise astronomical language and detailed description. For comparison, the annal for 729 simply says that 'two comets appeared near the sun and remained for about two weeks', omitting all the details provided by Bede as to exact locations, times of appearance, and possible significance. ${ }^{71}$ Similarly a comet which appeared in 975 was so important to the compilers of the Anglo-Saxon Chronicle that three versions commemorated it with five lines of verse. ${ }^{72}$ John of Worcester merely notes that 'a comet was seen in the autumn'. ${ }^{73}$

Relevant to this, and unique in the context of a chronicle, is the use of material from the astronomical treatises of Walcher of Malvern and Petrus Alfonsi. That John had actually been trained in the observations and calculations which they expounded is demonstrated by his account of the solar phenomenon of 1133. This had clearly been the subject of learned discussion, since John is able to record that the sun was totally obscured only in some parts of England. On the south coast, where the king was, the sun appeared like a new moon (though rapidly changing in shape). John records that 
some claimed that this was an eclipse of the sun, and inserts a passage from Walcher of Malvern's De dracone giving the relative positions on the ecliptic of the sun and the moon required for this. ${ }^{74}$ The positions he gives are those for a lunar, rather than a solar, eclipse, but he is the only chronicler to provide such a technical commentary. The trained reader, with access to tables of planetary positions for the date in question, is being given the information needed to carry out a reconstruction and analysis. Still further knowledge of, and interest in, astronomy is shown by the comments which follow, which record that the moon, when only three days old, suddenly appeared full (in other words, fourteen days old), and that 'others' saw two moons on the same night.

It is thus clear that John had actually been studying in this field, as the annal for 1138 also demonstrates. This includes the expected entries on political and ecclesiastical events, including a detailed account of the progress of the civil war. What is surprising is that John adds detailed information about the Arabic calendar, calculating that a new Arabic year had begun on $16^{\text {th }}$ September and that this is the year 537 of the 'Arab era'. He goes on to offer a slightly muddled comment about the complexities of the Arab system of dating. This information is linked to a reference to the 'Ezich' (or $z i j$ ) of al-Khwarizmi which, as John states, provides tables setting out the 'courses of the seven planets'. ${ }^{75}$ These tables were only just becoming available in England, in Latin translations by Adelard of Bath and Petrus Alfonsi, and they seem to have been in use by doctors and astrologers rather than by chroniclers. ${ }^{76}$ This makes the source of John's knowledge a matter of interest, since expertise in this field was the preserve of a tiny number of specialists in England at this time. John clearly took his new knowledge seriously. His annal for 1140 applies it again in describing the requisite positions of the sun and moon for the eclipse which took place that year, using terminology taken from Walcher of Malvern's exposition of Arab astronomy. That John had access to astronomical texts, and had been instructed in how to understand them, is demonstrated by the surviving collection of relevant treatises, now Oxford, Bodleian Library, Ms. Auct F I 9, partly in John's own hand.

This manuscript provides valuable information as to the knowledge which John acquired and its place in his work. The two texts which John himself copied are: Robert of Hereford's treatise on chronology and on the work of Marianus Scotus; and the computus of Gerland. The latter was another of the computists who noticed the problems in the work of Dionysius Exiguus. ${ }^{77}$ Also included in this manuscript are works on arithmetic, both basic and advanced, and on the related use of the abacus. John's knowledge of astronomy clearly relates to the materials assembled in folios 75 to 162 of F I 9 which are: a treatise on the astrolabe; Walcher of Malvern's 'Lunar Tables' and De dracone; and al- Khwarizmi's astronomical tables, as translated by Adelard of Bath. All these are very rare works, with De dracone known in only one other copy and the Lunar Tables in just two other complete copies. Even the tables of al-Khwarizmi survive in only six complete medieval copies and a collection of excerpts. In each case this Worcester collection stands early in the transmission of the text. $^{78}$ The final work in the collection is Macrobius, on the Somnium Scipionis, a traditional textbook for cosmology and dream interpretation. That John linked these materials directly to the rewritten annals in Corpus 157 is shown by his marginal annotations on folio 20v of F I 9. The main text is part of Gerland's computus, and the marginal notes consist of John's captions for the miniatures on pp 382 and 383 of Corpus 157 depicting the visions of Henry I. John's deployment in Corpus 157 of the 
Arabic term Ezich, coupled with comments on planetary positions and the Arab calendar, is itself directly based on the F 19 collection. His lack of confidence in the calculations is understandable since Adelard's very direct translation of al-Khwarizmi required its user to 'translate' the readings given in the tables into the Roman solar calendar - a complex proceeding as both months and years were calculated differently. $^{79}$

What needs to be emphasised is the rarity of such knowledge in England at this time amongst scholars overall. Basic introductions to the astrolabe were being copied and taught in the more advanced Schools of northern France by the middle of the eleventh century but this new knowledge does not appear to have crossed the Channel until the early twelfth century. ${ }^{80}$ It is possible that the Lotharingian Giso, John of Tours' predecessor as bishop of Bath and Wells (1061-88), had at least some training in this field. ${ }^{81}$ It is certain that his fellow Lotharingians, Bishop Robert of Hereford and Prior Walcher of Malvern, were experts. Adelard of Bath was connected to the familia of John of Tours, Bishop of Bath (d.1122) and travelled from Bath to France and Italy and then on to Sicily and Antioch in pursuit of scientific knowledge. He learned Arabic during his studies, translated al-Khwarizmi's zij, and made it available in England in or after $1126 .{ }^{82}$ Thus, slightly unexpectedly, John of Worcester takes his place as a member of the group of scientists, based in the west of England, whose work has been discussed by Southern and Burnett, amongst others. ${ }^{83}$

Even engagement with Arabic, in order to use the planetary tables as given here, is demonstrated by the F 19 collection. ${ }^{84}$ Arabic terminology and dates are highlighted in red in the main text, while transliterated sentences and mnemonics are added in the margins. Perhaps even more surprising is the inclusion of one of the earliest versions of an abacus text to give Hindu-Arabic numerals. ${ }^{85}$ This was not only extremely advanced but again suggests strong interest in actual practice, since the combination of Arabic numerals and use of an abacus would greatly facilitate the chronological and astronomical calculations incorporated into Corpus 157. The presentation of Henry I's visions, and the phenomena surrounding them, is thus far more than a simple collection of marvellous occurrences. The inclusion of Macrobius' treatise on the Dream of Scipio in the F 19 collection is also significant here. As mentioned above, this work deals with a dream-vision which has much to say on cosmology as well as offering historical information. It was thus a promising subject of study for those interested in the new astronomical knowledge. Worcester undertook such study precociously early; but a similar approach is found, for instance, in a mid-twelfthcentury manuscript from southern France. This is now NKS 218 4to of the Kongelige Bibliotek, Copenhagen, and it has, amongst other relevant additions to Macrobius' text, diagrams of solar and lunar eclipses added after the explicit of the main text. That dreams and visions were taken seriously as sources of information on the structure and workings of the universe is clear, and so also is the view that application of new astronomical knowledge to this information was appropriate. John of Worcester's use of Arabic numerals, mathematics and planetary tables is in the same mould, but even more impressive. As with Corpus 157's presentation of the Cross and the Crucifixion, the measurement of time and space is again given a spiritual overtone. Dreams and visions are emphasised as links between past, present and even future; and their role as keys to true understanding, for those equipped to interpret them, does much to explain the decision to insert unprecedented miniatures into the annal for 1130/1. 
As the fourth of these miniatures, the one which illustrates John of Worcester's own narrative, demonstrates, it took not just the sequence of dream-visions but also fear of death to make Henry I take his vow to remit taxes for seven years. The annal also makes a strong contrast between Henry's decision to undertake penance and Stephen's state of uncorrected perjury. As noted above, penance plays an important part in the annal for 1132 also, in the form of the description of how the Worcester monks violently aided the paralysed Uhtred in the remission of his sins. The same theme is emphasised by an addition entered in John's own hand into the margin of the annal for 741. This tells of how St Eucherius, then bishop of Orléans, had a vision in which he was taken ad alterum speculum and shown Charles Martel already being tortured, body and soul, in the lower depths of hell. An angel explained that this was in response to the request of the saints whose possessions Charles had seized. This outrage was so serious not only because of the insult to the saints but also because it had made Charles liable for the sins of all those who had given the property which he had seized.

Thus the miniatures of Henry I, and the complex texts surrounding them, make up more than 'an anthology of the interesting and the curious' ${ }^{86}$ There is a logic underlying the apparently unlikely combination of visions, dreams, portents, penance and cutting-edge science. John of Worcester appears to have agreed with both John of Salisbury and Orderic Vitalis that historical narrative can make visible the 'things of God' ${ }^{87}$ Here Isidore of Seville's discussion of signs, dreams and portents is crucial. Book Eleven of Isidore's Etymologies deals with 'Humanity and Portents' (De homine et portentis) with chapter III focusing on portents. Isidore explains that portents, signs, omens and prodigies all have two chief characteristics. Firstly they relate to future events; and secondly they are creations of God and thus are not in fact contrary to nature but only to what humans know of nature. As Isidore further observes, God also sometimes indicates what is to come through dreams and sometimes through oracles. The specialists in this field, as Book Seven, chapter VIII expounds, are the prophets, individuals chosen by God to foresee future events, and to 'pre-speak' them. A key point, once again, is that the interpretation of dreams was the special preserve of prophets.

The appearance of Daniel's name in John of Worcester's account of Henry I's dreams is particularly interesting given the significance of both his prophecies and Jerome's commentary for medieval views on the structure of world history. ${ }^{88}$ Jerome stated that Daniel's prophecies set out so much of later history that a careful reading of no fewer than fourteen ancient historians was required to understand him correctly; and emphasised that God gave Daniel a special gift of seeing what was to come through the interpretation of dreams, visions and 'shadowy appearances' (Commentary on Daniel, Chapter One, verse 17). ${ }^{89}$ No complete library-catalogue survives from Worcester priory; but amongst the early-twelfth-century manuscripts still at Worcester Cathedral is a copy of Jerome's equally standard work on the psalms (now Cathedral Library Ms F.81). A Worcester copy of a less well-known work, Jerome's commentary on six minor prophets, is now British Library, Ms Royal $4 \mathrm{C}$ ii. Given this, and Jerome's status in twelfth-century scholarship, it is extremely likely that John will have had access to the important commentary on Daniel. As both Jerome and Isidore make clear, visionary dreams require interpretation by someone with a special gift, since their meaning is by no means straightforward. Jerome points out 
that God sends such dreams to kings not because the kings themselves are pious but to make possible their interpretation by holy men and to increase the kings' respect for God (Chapter Two, verse 1). He adds that such royal dreams give warning of how kings and empires succeed one another, and how they are to be 'governed, altered and terminated' (Chapter Two, verse 21). It is thus appropriate for kings to seek to have visionary dreams interpreted, and to wish to know the future (Chapter Two, verse 30) though it is completely wrong for kings to turn to soothsayers for this purpose (Chapter Two, verse 27). God does send promises of indulgence for the king, as long as he does good works (Chapter Four, verse 20); but pride and failure to heed God's warning can lead to loss of the kingdom (Chapter Four, verses 28-9). The relevance of this for John of Worcester's presentation of the dreams of Henry I and the oathbreaking of Stephen is clear. As the miniatures show, Henry I did finally listen to his new Daniel and was thereupon granted a miracle. However, the early stages of Stephen's own reign are presented as marred by his failure to keep his oath on this issue.

One final problem remains: if the message is so simple, why should John of Worcester provide detailed astronomical data, when more standard notes on the eclipses, sunspots and midnight lights would suffice? The answer seems to be that John, like both a good historian and a good scientist, is providing full and accurate evidence, in order that readers can judge for themselves. To insert a direct interpretation would be to present himself as another new prophet; and this John does not undertake. Instead, the detailed notes on eclipses, and the reference to planetary tables, make available to the reader the very latest means for establishing whether a particular darkening of the sun was or was not an eclipse. This is important because, if portents and signs are revealed as such by being contrary to what is known about nature, then an eclipse is not in itself a sign, since eclipses are a standard (if rare) astronomical occurrence. Thus the descriptions of the solar, lunar and astral phenomena in 1128-31 are accompanied by diagrams, astronomical data, and notes for guidance, so that the ambitious reader can undertake a judgement. Equally, John does not attempt a direct interpretation of the dreams of Henry I. It is Grimbald whose advice to the king is quoted, and demonstrated to be wholly borne out. John's contribution is to show the dreams, their interpreter, and the miracle granted to Henry I; and to place these in contrast to Stephen's oath-breaking and its consequences. Finally, the materials assembled by John point to events even beyond the grave, since unjust rulers faced an eternity of punishment unless they paid attention to the need for penance. Here also John's technique is to present his evidence, in the form of long accounts of the visions granted to saints Eucherius and Odilia, but to provide no commentary.

The effect of the revisions, then, is to turn the Worcester 'chronicle of chronicles' into something more complex and more ambitious even than the work of Marianus. The placing of the short history of Worcester Cathedral Priory at the opening of the manuscript identifies it immediately as a Worcester product; whilst the addition of the typological miniature within a conspectus of world history and sacred geography is a powerful reminder that all actions must be understood as part of a vast pattern, governed by divine providence. In their turn the new, illuminated annals for 1128-31 powerfully inflect the reading of Corpus 157's subsequent account of the downward spiral of events in England after the death of Henry I. The annal for 1135 serves as a demonstration. Its description of the funeral of Henry I, at Reading abbey, stresses 
both the endowments which the king had given to his foundation 'for the good of his soul' and the offerings, alms and multiple masses which accompanied his burial. The poetic composition which follows emphatically wishes the king a speedy release from the pains of purgatory. By contrast, the rest of the annal records the breaking of both faith and peace in England and Normandy under the new regime. Its lament for the outbreak of oath-breaking and corruption of government in England, coupled with a reminder of purgatory, strongly echoes the themes emphasised under 1128-31. The account of the decline of the Anglo-Norman realm, and of England in particular, is both complex and, in its own terms, deeply learned.

How Corpus 157 ended cannot now be known since, as noted above, the manuscript ends imperfectly, and the reader is thus left with no conclusion. This is perhaps fitting for a chronicle which so strongly invited its readers to engage in their own meditation upon the meaning of history. Nevertheless this ambitious work begins to emerge as a major product of the English contribution to the renaissance of the twelfth century, as discussed by R.W. Southern and Rodney Thomson. ${ }^{90}$ Its bringing together of: the writing of history; scientific and mathematical advances; the literature of wonders; and innovative combinations of text, image and iconography, into a book of rich and impressive complexity, makes it one of the outstanding monuments to the movement. This chronicle is unique in its distinctively 'English' contribution to the key fields of history, science and book production.

\section{Acknowledgements}

I should like to thank the Librarian of Corpus Christi College, Oxford, for her kindness during my research for this article.

\section{Notes}

\footnotetext{
${ }^{1}$ This was one of the many achievements of the scholars who edited the published portions of the chronicle. See John of Worcester, The Chronicle of John of Worcester, 2: The Annals from 450 to 1066, ed. R.R. Darlington and P. McGurk, trans. J. Bray and P. McGurk (Oxfrod: Clarendon Press, 1995) and The Chronicle of John of Worcester, 3: The Annals from 1067 to 1140, ed. and trans. P. McGurk (Oxford: Clarendon Press, 1998). See especially Vol. 2, 'Introduction' pp. xvii-xix.

${ }^{2}$ Ibid., Vol.3, 142.

${ }^{3}$ That Florence's contribution remains to be determined was pointed out by Simon Keynes in his review of Volume 2; see Speculum, Vol. 72, No. 1(Jan. 1997): 177 - 79.

${ }^{4}$ Paul Hayward, ‘422: Sources for Medieval History', University of Lancaster, http://www.lancs.ac.uk/staff/haywardp/hist422/seminars/Worcester.htm. Accessed January 11, 2012.

${ }^{5}$ Hayward, ed. and trans., The Winchcombe and Coventry Chronicles: Hitherto Unnoticed Witnesses to the Work of John of Worcester, 2 vols., (Tempe, Arizona: Arizona Center for Medieval and Renaissance Studies, 2010) at p.8.

${ }^{6}$ The manuscript is Oxford, Corpus Christi College, Ms 157. High-resolution, digitised images of every folio and page of this complex manuscript are available at 'Early Manuscripts at Oxford University', Oxford Digital Library. http://image.ox.ac.uk/list?collection=corpus\&manuscript=ms157 (accessed April 2, 2012). Full details of other manuscript witnesses to the chronicle are given in the edition, as cited above. For discussion of the miniature see in particular C.M. Kauffmann, Romanesque Manuscripts, 1066 - 1190 ( a survey of manuscript illumination in the British Isles, III), (London: Harvey Miller, 1974) 87, no.55; and idem, 'Manuscript Illumination at Worcester in the Eleventh and Twelfth Centuries' in Medieval Art and Architecture at Worcester Cathedral, (British Archaeological Association Conference Transactions for 1975) 1978, 43-50. See also: L.M. Ayres, 'The Role of an Angevin style in English Romanesque painting', Zeitschrift für Kunstgeschichte 36, 1974, 193-223; M. Camille, 'Seeing and reading: some visual implications of medieval literacy and illiteracy', Art History 8, 1985, at 27-8; R. Gameson, 'St Wulfstan, the library of Worcester and the spirituality of the
} 
medieval book', in J.S. Barrow and N.P. Brooks, eds., St Wulfstan and his World, (Aldershot \& Burlington VT; Ashgate); F. Wormald, 'The Survival of Anglo-Saxon Illumination after the Norman Conquest', Proceedings of the British Academy XXX, 1944, 127-45.

${ }^{7}$ Orderic Vitalis, The Ecclesiastical History of Orderic Vitalis, II, Books III and IV, ed. and trans. M. Chibnall, (Oxford: Clarendon Press, 1969) 186-9.

${ }^{8}$ The translations are my own, and differ very slightly from Chibnall's.

${ }^{9}$ Ibid, 186 n. 1 and 187 n.4.

${ }^{10}$ See for instance P. McGurk, 'Worcester, John of (fl. 1095-1140)', Oxford Dictionary of National Biography, Oxford University Press, 2004 [http://www.oxfroddnb.com/view/article/48309, accessed 17 February 2012].

${ }^{11}$ Vol.2, xvii.

${ }^{12}$ M. Brett, 'John of Worcester and his contemporaries' in The Writing of History in the Middle Ages: Essays Presented to Richard William Southern, ed. R.H.C. Davis and M.H. Keen (Oxord: Clarendon Press, 1981) 101-26.

${ }^{13}$ Ibid., 125 .

${ }^{14}$ Ibid., 125-6.

${ }^{15}$ The seminal discussion is still N.R. Ker, 'Hemming's Cartulary: a description of the two Worcester Cartularies in Cotton Tiberius A. xiii' in Studies in Medieval History presented to Frederick Maurice Powicke, ed. R.W. Hunt, W.A. Pantin, R.W. Southern (Oxford: Clarendon Press, 1948) 49-75.

${ }^{16}$ Ibid., 65.

${ }^{17}$ See for instance Symeon of Durham, Libellus de Exordio atque Procursu istius hoc est Dunhelmensis Ecclesie, ed. and trans. D. Rollason (Oxford: Clarendon Press, 2000) 46.

${ }^{18}$ Chronicle of John of Worcester, 2, lix-lxiv.

${ }^{19}$ Ibid, xxxv-xlv.

${ }^{20}$ J. Collard, 'Henry I's dream in John of Worcester's Chronicle (Oxford, Corpus Christi College, MS 157) and the illustration of twelfth-century English chronicles', Journal of Medieval History Vol 36 (2010) 105-125, passim.

${ }^{21}$ William of Malmesbury, Saints' Lives, ed. and trans. M. Winterbottom and R.M. Thomson, (Oxford: Clarendon Press, 2002) p. Xv. Dedication to Warin in 'Letter', 8-9.

${ }^{22}$ On these scholars see: C.P.E. Nothaft, Dating the Passion: the Life of Jesus and the emergence of scientific chronology(200-1600), (Leiden, Brill, 2012) esp. chapter 3; and P. Verbist, Duelling with the Past: Medieval Authors and the Problem of the Christian Era (c990-1135), (Turnhout, Brepols, 2010).

${ }^{23}$ D. Feeney, Caesar's Calendar: Ancient Time and the Beginnings of History (Berkeley and London: University of California Press, 2007) 28 - 32.

${ }^{24}$ A copy of Marianus' work possibly known at Worcester in John's time is now London, British Library, Ms Cotton Nero C. V.

${ }^{25}$ See Argumenta titulorum paschalium, B. Kruscch, ed., Studien zur christlich-mittelalterlichen Chronologie. Die Entstehung unserer Leutigen Zeitrechnung, II, (Berlin, 1938) 76-7.

${ }^{26}$ Eusebius, Ecclesiastical History: 5.24; 7.20; and 7.32. See Eusebius' Ecclesiastical History to 324 $A D$, trans. C.F. Cruse (London: Bagster, 1847) 224, 300, $322-3$.

${ }^{27}$ C.H. Turner, 'The Paschal Canon of Anatolius of Laodicea', English Historical Review, X(XL), (1895) 699-710.

${ }^{28}$ See: Georges Declercq, 'Dionysius Exiguus and the introduction of the Christian era', Sacris Erudiri 41 (2002) 165-246; and A.A. Mosshammer, The Easter computus and the origins of the Christian Era (Oxford: Oxford University Press, 2008).

${ }^{29}$ For Dionysius' work see J.G. Pallares, 'Hacia una nueva edición de los Argumenta titulorum paschalium del Dionisio el Exiguo', Hispania sacra, 46 (1994) 13 - 31.

${ }^{30}$ For Bede's guarded comments see The Reckoning of Time, trans. F. Wallis, (Liverpool: Liverpool University Press, 1999) chapter 47, 126 - 9.

${ }^{31}$ J. Moreton, 'Before Grosseteste: Roger of Hereford and Calendar Reform in Eleventh- and TwelfthCentury England', Isis 86 No. 4 (1995): 562 - 86.

${ }^{32}$ William of Malmesbury, Gesta Pontificum Anglorum, ed. and trans. M. Winterbottom and R.M. Thomson (Oxford: Clarendon Press, 2007) 164.

${ }^{33}$ What has been identified as John of Worcester's own handwriting appears in Auct. F I 9; see Chronicle of John of Worcester, 2, xxix. On Cotton Nero C v and its relation to the Worcester chronicle see ibid., lxiv-lxvii.

${ }^{34}$ See $n 7$ above. 


\footnotetext{
${ }^{35}$ Hayward, op. cit., 8.

${ }^{36}$ P. Verbist, 'Reconstructing the Past; the Chronicle of Marianus Scotus' Peritia 16 (2002) 284-334.

${ }^{37}$ Chronicle of John of Worcester, II, xxxiv.

${ }^{38}$ S. Mereminskiy, 'Forging a Common Past: historiographical contacts of Durham monks in the twelfth century', conference paper, $3^{\text {rd }}$ Biennial Oxford \& Cambridge International Chronicles Symposium, Oxford, July 2012.

${ }^{39}$ M. Lapidge, Anglo-Latin Literature 90-1066, (London: Hambledon, 1993) 294.

${ }^{40}$ For analysis of the collation of Corpus 157 see ibid., xxii. A slightly different analysis is given by R.M. Thomson, in his description of the manuscript; see Descriptive Catalogue of the Medieval Manuscripts of Corpus Christi College, Oxford: Western Manuscripts, (Woodbridge: Corpus Christi College and Brewer, 2011).

${ }^{41}$ C.M. Kauffmann, 'Manuscript Illumination at Worcester', 46 and n32; and Romanesque Manuscripts at number 55, citing R.B. Green, 'A Typological Crucifixion' in Festschrift Ulrich Middeldorf, 1968, $20-3$.

${ }^{42}$ H. Swarzenski, Monuments of Romanesque Art, (2 ${ }^{\text {nd }}$. Ed., London: Faber, 1954), 60.

${ }^{43}$ C.M. Kauffmann, Biblical Imagery in Medieval England, 700 - 1550 (London: Harvey Miller, 2003) 80.

${ }^{44}$ Ibid.

${ }^{45}$ Eusebius, Life of Constantine the Great, trans. T.R. Cushing, in Nicene and Post-Nicene Fathers $2^{\text {nd }}$.
} Series Vol. 1, ed. P. Schaff and H. Wace (Buffalo, New York: Christian Literature Publishing Co., 1890).

${ }^{46}$ De Civitate Dei, Book XVIII, chapter 23. See E. Hoffmann, ed., Corpus Scriptorum

Ecclesiasticorum Latinorum, Vol. XXXX Pars II (Prague: Tempsky, 1900) 297 - 300.

${ }^{47}$ See B. Thompson, 'Patristic use of the Sibylline oracles', Review of Religion 16, 1952, 115-36; and F.J. Dölger, Das Fischsymbol in Frühchristlicher Zeit (1928) 8. (I am grateful to Michael Kauffmann for this reference.)

${ }^{48}$ Collard, 'Henry I's Dream'; Kauffmann, Romanesque Manuscripts, 16-17.

${ }^{49}$ The Liber vitae is now B.L. Ms Stowe 944.

${ }^{50}$ Chronicle of John of Worcester 2, xlvi-liii; Brett, 'John of Worcester', 107-8. For a photograph of Bodl. 297's version of the Crucifixion miniature see O. Pächt and J.J.G. Alexander, Illuminated Manuscripts in the Bodleian Library Oxford, 3, (Clarendon, Oxford) 1966, no. 167, pl. 17.

${ }^{51}$ See E. Mâle, Religious art in France, a study of medieval iconography and its sources, (London, Dent) 1913, Vol 1, 177.

${ }^{52}$ See T.A. Heslop, 'The English Origins of the Coronation of the Virgin', The Burlington Magazine, 147 (Dec. 2005) 790-97.

${ }^{53}$ Chronicle of John of Worcester 2, xxix.

${ }^{54}$ See N. Stratford, 'Notes on the Norman Chapterhouse at Worcester' in Medieval Art and Architecture at Worcester, 51 - 70, and Kauffmann, Biblical Imagery, 80 - 84.

${ }^{55}$ T.A. Heslop, 'Worcester Cathedral Chapter House and the Harmony of the Testaments', in New Offerings, Ancient Treasures: Essays in Medieval Art for George Henderson, ed. P. Binski and W. Noel (Stroud: Sutton, 2001) 281-311.

${ }^{56}$ T.A. Heslop, website: 'Virtual Worcester Chapter House', www.uea.ac.uk/ $\neg 042 /$ accessed 6 Aug 2012.

${ }^{57}$ Brett, 'John of Worcester' passim. See also John of Worcester 2, 1xvii-lxxxi.

${ }^{58}$ Ibid., passim; and Chronicle of John of Worcester, 3, xix-xxxii.

${ }^{59}$ Brett, 108-9 and Chronicle of John of Worcester, 2, xxxv-vi.

${ }^{60}$ See John of Worcester 3, xlviii-1 and 290-305.

${ }^{61}$ For the development of this story see T. Licence, 'History and Hagiography in the Late Eleventh Century: The Life and Work of Herman the Archdeacon, Monk of Bury St Edmunds', English Historical Review Vol. CXXIV No. 508 (June 2009), 516-44.

${ }^{62}$ John of Worcester 3, 202-3.

${ }^{63}$ For discussion see M.E. Fassler, 'The Office of the Cantor in Early Western Monastic Rules and Customaries: A Preliminary Investigation', Early Music History, 5 (1985) 29 - 51.

${ }^{64}$ See S.C. McCluskey, 'Gregory of Tours, Monastic Timekeeping, and Early Christian Attitudes to Astronomy', Isis, 81, No. 1 (1990) 8 - 22.

${ }^{65}$ See F. Wallis, '8. Mathematics: fols. 41v-58r', The Calendar and the Cloister: Oxford, St John's College Ms 17, 2007, McGill University Library Digital Collections Program, http://digital.library.mcgill.ca/ms-17 (accessed Aug. 15, 2012). 
${ }^{66}$ Lanfranc, The Monastic Constitutions, ed. and trans. Dom D. Knowles and C.N.L. Brooke, (Oxford: Clarendon Press, 2002) 123 and 127.

${ }^{67}$ See G. Beaujouan, 'The Transformation of the Quadrivium' in Renaissance and Renewal in the Twelfth Century, ed. R.L. Benson and G. Constable (Boston, Mass.: Harvard UP, 1991) 463-87.

${ }^{68}$ William of Malmesbury, Vita Wulfstani I, 3, 24-5.

${ }^{69}$ See for instance Chronicle of John of Worcester, 3, 182-3.

${ }^{70}$ Ibid., $198-9$.

${ }^{71}$ 2, 180-81; and Bede, Historia Ecclesiastica, Book 5, chapter 23.

${ }^{72}$ On this see S. Keynes, 'The Comet in the Eadwine Psalter', Gibson, Heslop and Pfaff, eds., The Eadwine Psalter, Text, Image and Monastic Culture in Twelfth-Century Canterbury, (London and University Park: MHRA and Penn State University Press, 1992) 157-64.

${ }^{73}$ Chronicle of John of Worcester, 2, 428-9.

${ }^{74} 3,210-11$, and n.2.

75 Ibid, $258-61$.

${ }^{76}$ R. Mercier, 'Astronomical Tables in the Twelfth Century' in Adelard of Bath: an English Scientist and Arabist of the Early Twelfth Century ed. C. Burnett (London: Warburg Institute, 1987) 87 - 118.

${ }^{77}$ Moreton, op. cit., $565-6$.

${ }^{78}$ Burnett, Adelard of Bath, 166-92.

${ }^{79}$ Mercier, op. cit., 89.

${ }^{80}$ C. Burnett, The Introduction of Arabic Learning into England (London: British Library, 1997) 5 - 8.

${ }^{81}$ On Giso see S. Keynes, 'Giso, Bishop of Wells' in Anglo-Norman Studies XIX, 1997, 203-72.

${ }^{82}$ Ibid., 29.

${ }^{83}$ R.W. Southern, 'The Place of England in the Twelfth-Century Renaissance', in idem, Medieval

Humanism and Other Studies, (Oxford: University Press, 1970) 158-80; and Burnett, 'Mathematics and Astronomy in Hereford and its Region in the Twelfth Century', in D. Whitehead, ed., Medieval Art, Architecture and Archaeology at Hereford, British Archaeological Association Conference Transactions XV, 1995, 50-59.

${ }^{84}$ Burnett, Introduction, 40.

${ }^{85}$ Burnett, 'Mathematics and Astronomy in Hereford and its Region in the Twelfth Century', at 52.

${ }^{86}$ Collard, op. cit., 125.

${ }^{87}$ C.S. Watkins, History and the Supernatural in Medieval England (Cambridge: Cambridge University Press, 2007) 15.

${ }^{88}$ C. Given-Wilson, Chronicles: The Writing of History in Medieval England, (Hambledon \& London, Continuum) 2004, 115.

${ }^{89}$ For the Latin text see Patrologia Latina XXV, cols. 491-584. For translation, G.L. Archer, Jr., St Jerome; Commentary on Daniel, (Grand Rapids, Michigan: Baker Book House, 1958).

${ }^{90}$ Southern, 'Place of England'; R.M. Thomson, 'England and the Twelfth-Century Renaissance', Past and Present 101, November 1983, 3-21. 